\title{
URBAN REACTIONS TO THE GLOBAL WARMING ISSUE: AGENDA SETTING IN TORONTO AND CHICAGO
}

\author{
W. HENRY LAMBRIGHT \\ Center for Environmental Policy and Administration, The Maxwell School of Citizenship and Public \\ Affairs, Syracuse University, Syracuse, NY 13244-1090, U.S.A. \\ STANLEY A. CHANGNON \\ Illinois State Water Survey, Champaign, IL, U.S.A. \\ L. D. DANNY HARVEY \\ Department of Geography, University of Toronto, 100 St. George Street, Toronto, Canada M5S 1AI
}

\begin{abstract}
Little research has been done about what cities could or should do concerning potential global warming. A few cities have adopted programs to deal with impacts they perceive may occur, and a worldwide network of 100 cities involved with $\mathrm{CO}_{2}$ reduction has recently emerged. Global warming is a new issue for cities and most are only dimly aware of how it may affect them. Toronto, through the efforts of a few leaders, has become a pioneer in the development of an urban response program to global warming. It has charged a city agency to deal with global warming issues, in particular emissions reduction. Chicago is aware of the issue and is concerned about the negative impacts global warming could produce. While behind Toronto, Chicago is moving forward in a number of areas. These two cities illuminate the policy-making process for global warming at the urban level and the role 'policy entrepreneurs' can play at this level. In comparing the two cities, a common model of policy development is utilized.
\end{abstract}

\section{Introduction}

In spite of growing concern about global warming and its impacts on society (Oppenheimer and Boyle, 1990; Feldman and Mann, 1991; Schneider, 1989), there is considerable uncertainty over what should be done, by whom, when, and how. Some see the scientific uncertainties and counsel knowing more before acting (Global Climate Coalition, 1994), while others propose action 'just in case' (Global Environmental Change Report, 1994). In both cases, it is generally assumed that national-level governments have the most important, if not the only role to play, either in funding research or implementing policies to restrict greenhouse-gas emissions. In the case of the United States, the federal government has substantial research efforts under way to assess global change (Committee on Environment and Natural Resources, 1994). The current federal policy, as summarized in the U.S. Climate Action Report (U.S. State Dept., 1994), aims to reduce $\mathrm{CO}_{2}$ emissions in 2000 to the 1990 level through voluntary programs.

However, an effective response to the risks posed by continuing emissions of greenhouse gases will require carefully coordinated actions involving all levels of government: national, regional (state or provincial), and local. To date, there has 
been only limited discussion of the potential role of regional and local governments in policy responses to global warming concerns (i.e., Morandi, 1991; Jones, 1991; Harvey, 1992, 1993, 1995; Changnon, 1995). The United Nations Framework Convention on Climate Change requires signatory countries, "to develop national and, where appropriate, regional action plans ..." but does not explicitly refer to the role of municipal governments in addressing greenhouse-gas emissions.

Global warming is a new issue for cities, and most cities still perceive it as an issue falling under the jurisdiction of higher levels of government rather than as an issue to which they can respond. Nevertheless, there is a growing awareness among municipal governments that cities have an important role to play in reducing greenhouse-gas emissions, which has led to the formation of a number of municipal global warming networks and the development of municipal action plans in some cities.

This paper briefly describes the emerging municipal global warming networks, then compares the state of awareness and action on global warming in two cities - Toronto and Chicago. It analyzes the policy processes leading to municipal response. We develop a model whereby the development of a municipal response evolves through the following stages: (a) awareness of need; (b) trigger for action; (c) planning; (d) adoption; (e) implementation; and (f) institutionalization. Some cities (and specific governmental functions within cities) are further along than others in terms of this continuum.

\section{Cities and Climate Change}

Much of what has been written about cities and climate-change concentrates on the most dramatic problems: namely, sea-level rise (i.e., Hoffman et al., 1983; Davidson and Kana, 1988; McCulloch, 1992a), reductions in municipal water supply (i.e., Dalfes, 1992), or exacerbation of pre-existing ozone (smog) pollution problems (Green, 1992; Edgerton, 1992; Foute and Andrews, 1992). Interestingly, Davidson and Kana (1988) conclude that, "Communities cannot prevent global warming; they can, however, aggravate or mitigate its impacts", which reflects the prevailing view that prevention of future global warming (beyond that to which we are already committed) is something outside the jurisdiction of cities.

A few cities are planning for global climatic change, perhaps none more grandly than Tokyo (Nishioka et al., 1992). Officials from Tokyo claim to think globally and act locally, and speak of 'the sustainable city'. There is planning underway in Japan to 'restructure' cities to make them more resilient and less vulnerable to climate change. Attention is given to 'Urban Ecology Indicators'. The aim of this planning is to make a city like Tokyo less a problem-producer (through pollution). One of the 'technological fixes' that might be applied to mitigate global warming in Tokyo is a permeable pavement, which would allow precipitation to penetrate and enrich groundwater. It is noteworthy that the Japanese national government considers the 
role of cities in its environmental planning. The New York Times reports that Japan has adopted, via MITI, a "100-year blueprint that lays out, decade by decade, the key steps needed" to confront global warming. The restructuring of Japanese cities is part of this plan (Boffey, 1992).

A number of cities are collaborating as part of the Urban $\mathrm{CO}_{2}$ Project to develop policies to reduce their own $\mathrm{CO}_{2}$ emissions (Harvey, 1993). The Urban $\mathrm{CO}_{2}$ Project is one of several projects carried out by the International Council for Local Environmental Initiatives (ICLEI), which was established in 1990 and has headquarters at Toronto City Hall. Participants in the Urban $\mathrm{CO}_{2}$ Project include: Dade County (Miami), Florida; City and County of Denver, Colorado; San Jose, California; Portland, Oregon; Minneapolis and St. Paul, Minnesota; Toronto and the Municipality of Metropolitan Toronto, Canada; Helsinki, Finland; Hannover and Saarbrücken, Germany; the Municipality of Greater Ankara, Turkey; and Copenhagen, Denmark (ICLEI, 1991). Each participant in the Urban $\mathrm{CO}_{2}$ Project submitted an action plan to reduce $\mathrm{CO}_{2}$ emissions by 1993 and was expected, in most cases, to commit to reducing $\mathrm{CO}_{2}$ emissions from energy use in its jurisdiction by 10-20\%. A summary of the targets adopted by each city and of the corresponding action plans, as well as a full discussion of Toronto's action plan, can be found in Harvey (1993). The Urban $\mathrm{CO}_{2}$ project has recently been expanded to a Cities for Climate Protection effort involving 100 cities.

The key actors within ICLEI cities are the municipal Environmental Protection Agencies or their equivalent. The Urban $\mathrm{CO}_{2}$ Reduction Project allows cities to get together and discuss mutual problems and solutions. With funds from foundations and other sources, the Urban $\mathrm{CO}_{2}$ Reduction Project has a budget running at about $\$ 300,000$ a year. The emphasis is on prevention and mitigation - what can cities do to prevent and mitigate the greenhouse effect? Assessment of the literature indicates that, in general, European cities are ahead of Canadian cities on the climate-change issue, but that Canadian cities are ahead of U.S. cities. It is noteworthy that Toronto provides office space for ICLEI and some funds toward staff support. The fact that it does so points up the lead role Toronto has chosen to play in the climate-change field. We will discuss Toronto, and then an American city with urban $\mathrm{CO}_{2}$ interests, Chicago.

\section{Toronto}

Toronto is a city of 620,000 that is the heart of an urban region of almost 4 million in population, whose population is expected to increase by 50 percent by 2021 . There is a two-tier government structure, with a metropolitan government overlying a number of municipal governments, including the city of Toronto. We will apply the aforementioned policy development model to analyze how Toronto has dealt with the global warming issue from a policy perspective. 


\subsection{AWARENESS}

There was general awareness in Toronto about the greenhouse effect by the mid$1980 \mathrm{~s}$ as a result of several topical reports in the media and technical discussions among scientists and urban leaders.

\subsection{TRIGGER}

Policy action began in 1988, the year of the long hot summer in which NASA scientist James Hansen declared before Congress that the greenhouse effect was here (Oppenheimer and Boyle, 1990). The specific catalyst was a major international conference, held in Toronto in 1988, sponsored by the Canadian federal government. It was called 'Changing Atmosphere', with approximately 500 people attending, including numerous top scientists and government officials. The theme of the conference was the seriousness of the risks associated with the enhanced greenhouse effect, in spite of its uncertainties.

This message impressed and deeply concerned a member of the Toronto City Council who attended the conference. This was Tony O'Donohue, a senior politician with considerable influence in Toronto. A civil engineer by training, he had a strong personal interest in energy and environmental issues and strong credibility with other members of the City Council regarding such matters. He had 'looked down the road' to the future of fossil fuels and had also worked with less developed countries in Central America in regard to their development problems. With this background, O'Donohue felt global warming was an issue for which he should supply leadership.

\subsection{PLANNING}

After the Changing Atmosphere Conference, O'Donohue pushed through the city government the establishment of a 'Blue Ribbon Committee' referred to as the Special Advisory Committee on the Environment (SACE). Those on the Committee consisted of a number of Toronto leaders and scientists who had attended the Conference, including one of us (LDDH).

SACE produced a two-volume report which reinforced what had been said at the conference, and which also took a local perspective on issues (Special Advisory Committee, 1991a, b). Originally, many on the Committee doubted that the city could do anything substantial about this global problem. But once they began considering possibilities, the Committee realized that any implementation of national or even international policies would come down to actions at the local level, where people lived, traveled, and worked.

The key recommendations of SACE were that Toronto: (1) adopt a target of a 20 percent reduction from 1988 levels of carbon dioxide emissions by the year 2005; (2) establish an atmospheric fund to help pay for needed demonstration projects 
and other changes; and (3) create a city energy-efficiency office to generate energyefficiency improvements in buildings.

\subsection{ADOPTION}

In 1990, O'Donohue shepherded the SACE recommendations through the City Council and Mayor's office, thereby making Toronto one of the first, if not the first, city in the world to have a local climate-change policy. Among the impacts that concerned everyone was the possible drop of Great Lakes water levels as a result of global warming. This would have serious impacts on water quantity and water quality. There could also be implications for the Niagara River and the power supplied by hydro plants using the outflow from Lake Erie. The St. Lawrence Seaway could also be negatively affected, and thus subsequently the economy of the region. However, when certain city commissioners were asked by the committee of the City Council charged with drafting a response to the SACE report, they cited concern over the general well-being of future generations for the next several centuries as an important reason for proceeding with the SACE recommendations. This concern with inter-generational impacts of global warming is consistent with the results of the surveys in the U.S. and Europe cited by Kempton (1991) and Kempton and Craig (1993).

A practical politician, O'Donohue was owed debts from the other members of the Council and the Mayor that he was able to cash in, with the result that the three key recommendations of SACE, listed above, were adopted. Most importantly, the Toronto Atmospheric Fund was created and provided with an endowment of $\$ 23$ million. This fund came in large part from land sales that had turned a profit for the City (O’Donohue, 1992; Harvey, 1992).

\subsection{IMPLEMENTATION}

In 1991, the Energy Efficiency Office (EEO) was established in the Department of Public Works and Environment. It was to be the administrative spearhead for $\mathrm{CO}_{2}$ reduction projects. Among the initial tasks carried out by the EEO were: (1) the development and implementation of a program to retrofit all city-owned buildings and facilities to improve energy efficiency; (2) the development and implementation of a program to upgrade efficiency of street-lighting; (3) review of proposals for new private and public-sector buildings with regard to energy and water use; and (4) an automobile program (the city would not accept cars into its fleet unless they minimized various pollutants, including CFCs).

The Toronto Atmospheric Fund (TAF) was constituted as a legally independent entity with a board of directors appointed by the City Council, with the intent to make it difficult for the City Council and others to raid the fund, and to insulate it from changing political fashion. The TAF is currently applying for charitable status with the Canadian tax department so that corporations and private individuals can 
receive tax deductions for contributions. The Fund is or will be used in two ways: (1) by lending its endowment for energy efficiency projects which generate a cost savings, with the principle plus interest paid back to the fund; and (2) by using the interest from (1) as a source of revenue for grants to leverage additional funding from other sources for demonstration projects involving advanced techniques and technologies for reducing $\mathrm{CO}_{2}$ emissions.

It was the intention of SACE to 'institutionalize' the process of change by having the City adopt a formal target for $\mathrm{CO}_{2}$-emission reduction and through the establishment of the EEO and TAF. This seems to be taking place, in that $\mathrm{CO}_{2}$ emission reduction has acquired a momentum of its own in Toronto, with further significant initiatives proceeding with very little input from SACE. Three major initiatives are: (a) plans to develop electricity-district heating cogeneration and district cooling in the downtown core; (b) plans for a program to retrofit the entire building stock of the City to the full economically justifiable energy and water savings potential; and (c) continuing efforts to encourage population growth in the City, rather than in the urban fringe. Aiding these climate-change initiatives is the fact that the primary motivation for pursuing each of these initiatives no longer seems to be strictly environmental, as explained below.

With regard to district heating and cogeneration, the City Council directed the Toronto District Heating Corporation, which currently provides only steam to buildings in the downtown core, to pursue opportunities to expand its service area and customer base wherever possible and to develop district cooling loops on an opportunistic basis, while pursuing discussions with the provincial utility and other parties for eventual cogeneration of electricity at one or more downtown sites. While such measures can lead to significant $\mathrm{CO}_{2}$-emission reductions, as discussed in Harvey (1993), the primary motivations at the local political level are the significant cost savings to Toronto businesses and the increased tax revenue for the City that would result.

The City's Department of Public Works and the Environment commissioned a study, completed in 1994, of possible financial mechanisms and institutional structures for carrying out a comprehensive retrofit of the entire building stock of the City to reach its full, economically attractive energy and water savings potential. Key concepts under consideration at the time are discussed in Harvey (1995). The most innovative is the intention to use private capital to fund the project with about $10 \%$ public sector funds serving as securitization in the event of building owner default, and recovery of outstanding loans by the City through property taxes. As of this writing, it is planned to begin with a two-year pilot project which will involve a cross section of about $1 \%$ of the floor space in the City. A request for proposals from financial/engineering/management consortia was issued and responses have been received. Interestingly, during public deputations involving the retrofit project, the prospect of significant job creation was frequently cited as an important reason to move forward. 
For many years, the City of Toronto has had a policy to encourage residential development in the downtown core and elsewhere in the city so as to achieve a rough balance with continuing growth of commercial office space, so that those filling new jobs are not forced to live in and commute to and from the suburbs. This process of increasing residential densities in the already urbanized area is referred to as urban 'intensification'. This policy clearly leads to reduced growth of $\mathrm{CO}_{2}$ emissions, in that people who live in proximity to work can (and, in the case of Toronto, often do) use transit or other alternatives to the automobile. Intensification policy is now cited by City officials as one of the measures Toronto is taking to reduce $\mathrm{CO}_{2}$ emissions. It is one reason for the small per capita automobile use in the City of Toronto, by North American standards (Newman and Kenworthy, 1989). Nevertheless, urban intensification receives its strongest support from a number of social activist groups and planners who cite the improved safety and 'livability' associated with a greater resident population, the opportunities to improve existing public transit services, and the fact that certain vulnerable groups are disadvantaged in an automobile-dependent society.

\subsection{CONCLUSION}

What has made it possible for Toronto to be so relatively active? One factor lies with the long tradition of environmental consciousness in the city. Toronto has energetic environmental groups, and environmental issues are given a place on the local government agenda by policymakers. A second factor was the existence of an influential proponent. Politically skilled, this proponent was from the conservative side of the ideological spectrum. This gave him a credibility that would not have been the case with a politician more clearly identified as an environmental spokesman (Jessup, 1992). The third factor is the widespread recognition that economic and other benefits will accrue from initiatives in the name of climate change. This has given $\mathrm{CO}_{2}$ reduction a life of its own and a broader constituency.

At the moment, therefore, Toronto is a pacesetter among urban governments in greenhouse policy. There is a loose coalition of scientific, bureaucratic, environmental, and political advocates. One takes away from interviews in Toronto a sense of zeal for the climate-change issue from at least a small band of actors with influence.

\section{Chicago}

Chicago is a city of 3 million, part of a metropolitan area of 7.4 million - one-half the population of Illinois. Global warming can be said to be moving slowly up the agenda of Chicago. It is not as far along the policy development cycle as in Toronto, but it is making progress.

There has been no self-conscious 'climate policy', as in Toronto. There are a number of policies that relate to climate indirectly. Policy for Chicago is made in 
many jurisdictions, with varying degrees of concern and response. In September 1995, Mayor Richard Daley, Jr. signed an agreement to participate in "Cities for Climate Protection Campaign", an ICLEI program that has the promise of a more comprehensive identification of climate as an issue. That marks a milestone, and perhaps a step towards a more conscious policy.

The march to this point has been slow and fragmented. This discussion of Chicago notes how the issue has moved to a point of awareness by a number of major actors in Chicago affairs, including some who are independent of the municipal government. It emphasizes an analysis of the policies of Chicago government per se, where there has been a measure of policy development.

\subsection{AWARENESS}

Many of the governmental and nongovernmental actors in Chicago climate policy are aware of the global warming issue. Among the non-local government organizations that could be relevant to an overall climate policy in Chicago is the Metropolitan Water Reclamation Agency. This is a regional special purpose agency with a prime mission of sewage treatment to protect Lake Michigan (Macaitus, 1992). The agency is well-regarded in the sanitary engineering field. With 2400 employees and an annual budget of $\$ 752$ million, it is a major force on the Chicago scene. The officials are aware of the global warming trend and its implications for them. For example, if, as it has been speculated, global warming causes the level of Lake Michigan to drop, the watering system used to treat sewage and protect the Lake's quality would be affected adversely. At a certain point, the agency would have to dredge the total canal system, at a cost of many millions of dollars (Changnon, 1993). The agency has taken a skeptical position concerning global warming. What would cause it to change its organizational view? A clear statement from federal or Illinois EPA that the risk was clear and present might have that effect. In that case, MWRA could build facilities to guard against global warming, a lengthy process in any event.

Commonwealth Edison, another major local actor, is the principal power utility serving Chicago. The most nuclear intensive utility in the United States, Commonwealth Edison does not contribute to the global warming problem to the extent other utilities that rely on fossil fuel do. Climate change is on the agenda of Commonwealth Edison, in the awareness stage. However, the utility also regards the issue as somewhat speculative.

Nevertheless, Commonwealth Edison has considered the potential impacts of global warming. If global warming came to Chicago, the summer demand for power would soar, and Commonwealth's capacity would be tested. The company has financial problems and the Illinois regulatory agency that oversees it does not want to add new capacity. As the utility sees it, it is being asked to plan for the dire consequences of global warming, but not being allowed to add to capacity to deliver power. Conservation and sharing power from other utilities, including some 
in Canada, are alternative options. However, Commonwealth Edison is not sanguine about these options. There have been two major heat waves hitting Chicago recently, in 1988 and 1995. Thus far, the utility has been able to cope, but if global warming turns out to be serious, the utility may be tested gravely.

The Illinois Division of Water Resources (DOWR) is a state agency that deals with an issue vital to Chicago-water. The city's water comes from Lake Michigan, and the DOWR issues permits for water use from the Lake. One-half of the State's population relies on Lake Michigan for drinking water, including Chicago. There are also commercial and recreational users, as Illinois has 60 miles of lake shoreline, one-half on public lands.

If some of the projections of water loss from the Great Lakes due to global warming occur, the impacts would exceed the current water management options available to the agency. Water quantity and quality would be threatened for Chicago and its neighbors.

Obviously aware of the global warming threat, the agency points to 1988 as an indicator of what would happen. There was a widespread drought that dropped Lake Michigan 1 meter from a record high. There was at the same time an Illinois proposal for diverting Lake Michigan water to help raise the Mississippi River whose level had also dropped due to the drought (Changnon, 1989). However, the other lake states and Canada objected. The controversy was sufficient to prevent the diversion option from being pursued.

Also, in 1988, water conservation had to be imposed by the DOWR and enforcement became a problem. There was conflict among communities, which varied greatly in water needs and ability to pay for them. All in all, the water issue is seen as a serious one if global warming is a reality.

There is thus awareness on the part of a number of organizations that have a strong impact on the city, but which are not part of the local government. However, they have not gone much beyond awareness. The City of Chicago, in contrast, has consciously moved further in its climate-change efforts in those areas where circumstances permitted.

While Chicago does not have a comprehensive climate policy per se, the local government has a set of $\mathrm{CO}_{2}$-reduction programs and may be on its way to a more self-conscious climate policy (Boldt, 1995a, b). The locus of municipal action on $\mathrm{CO}_{2}$-reduction programs is the Department of Environment (DE), created by Mayor Daley in 1992 (Inman, 1992; Williams, 1992; Ferg, 1992). This is an agency that pulls together a range of activities from other parts of government, and has given certain efforts in energy conservation/pollution prevention a new and stronger push than heretofore.

$\mathrm{DE}$ is a regulator, a 'doer' in the sense of running programs, and a catalyst in getting others to work together. With a staff of 85 people and budget of $\$ 8.5$ million, only a minority of staff work on enforcement activities. The Commissioner of Environment, Henry Henderson, is the Mayor's principal appointee on environmental matters. A strong Mayor, Daley is controversial with environmentalists, but 
there is evidence that he cares about certain facets of the environment, especially esthetics.

Chicago's City Council is also a force for environmental policy. The key actor is Mary Ann Smith, whose district is densely populated and heavily impacted by traffic and air pollution from vehicles. She is regarded as influential with Daley and has been a major ally of the Department of Environment and the program it has developed related to climate change. The evolution of Chicago climate policy, however, goes back to 1989 , before DE was even formed.

\subsection{TRIGGER}

As with Toronto, it took a specific trigger to go beyond awareness of global warming/climate change in a vague sense to policy action. Whereas the trigger was relatively direct in Toronto, it was indirect in Chicago.

In 1989, Mayor Daley read an article in a paper telling of Edith Makra, an environmentalist and urban forester, who was promoting tree planting in Chicago (Makra, 1992). The Mayor personally called Makra and persuaded her to join his administration to launch a tree-planting program for the City. For the Mayor, the benefits were beauty and economics (tourism). For Makra, these mattered, but she also saw the linkage with global warming. She knew that trees could help absorb $\mathrm{CO}_{2}$ and ground-level ozone (smog), although the direct effect of trees in absorbing $\mathrm{CO}_{2}$ is relatively limited. For Chicago, the most concrete local manifestation of global warming might be an increase in urban smog. Smog is an issue for the Chicago Lung Association, which is the most vocal of the local environmentalist groups for $\mathrm{CO}_{2}$ reduction, owing to the health impacts of smog. Chicago must deal with EPA which has found Chicago out of compliance on occasion with its ozone standards. Thus, as in the case of Toronto, a primary motivation for a $\mathrm{CO}_{2}$ program is a non-climate consideration.

\subsection{PLANNING}

The next step was for Makra to work out an arrangement with the U.S. Forest Service, which had interests both in urban forestry and finding a role in global warming mitigation. From 1988-91, planning was underway, with the city and Forest Service each spending $\$ 10,000$ for this effort.

\subsection{ADOPTION}

Then came adoption of a policy. In 1992, Congressman Sidney Yates of Chicago added $\$ 900,000$ to the Forest Service's budget, earmarking this for a three-year national demonstration of what trees could do to benefit a city and at the same time mitigate global warming (Chicago Urban Forest Project, 1992). 


\subsection{IMPLEMENTATION}

Implementation proceeded and the Chicago Urban Forest Climate Project, as it was called, was moved into the newly established Department of Environment. Soon after it was moved to DE, Karen Nowacki took charge of the forestry program and it became known officially as "Mayor Daley's Green Streets" project. The City, U.S. Forest Service, and various local universities worked closely together. Implementation of the tree program moved smoothly. After three years and hundreds of thousands of trees planted, the demonstration project was hailed as a success - an example of a 'no regrets' climate policy - at an international conference (Smith, 1995). Up to seventy-five percent of these trees have survived, and additional trees continued to be planted using City funds. The mayor would continue to identify closely with the program (Nowacki, 1995).

\subsection{FURTHER ADOPTION/IMPLEMENTATION}

Thus did climate policy get on the Chicago municipal agenda, in the name of urban forestry. It would be the forerunner of other programs that were adopted and implemented for other purposes, but which were climate-change related, and had the effect of $\mathrm{CO}_{2}$ reduction. Key to them all was DE. DE was a home and base for various programs. In the absence of an all-embracing policy, these piecemeal programs were de facto policy. There are three especially worth mentioning: building conservation; district heating and cooling; and transportation.

\subsubsection{Buildings}

Prior to the creation of $\mathrm{DE}$, there had been an energy-conservation program for buildings under Charles Williams in the Department of Planning. With the reorganization of this program under $\mathrm{DE}$, Williams revitalized the conservation in buildings effort and gave it more of an environmental cast. It became 'Green Buildings', and Williams worked hard to obtain cooperation from other local agencies, as well as technical assistance and national recognition from the Environmental Protection Agency (EPA).

Under this program, buildings were retrofitted. Changes included improvements in lighting, heating, ventilation, and air-conditioning systems, as well as the building's 'envelope'. The building energy-efficiency program was motivated primarily by the savings available and the opportunity to finance building improvements through those cost savings without using scarce City resources. The environmental benefits served as a welcome bonus and an additional incentive.

Chicago recently sought Department of Energy funding from the DOE's Climate Initiatives Program, 'Rebuild America'. This was to aid commercial building retrofit. The proposal was not funded, but Chicago has nevertheless on its own established an educational program aimed at commercial building owners in the City. This was linked to the CFC transition taking place. Under the Clean Air 
Act, the CFCs that most large air-conditioning systems in Chicago use will no longer be produced. To accommodate the phase-out in the availability of CFCs will require replacing or retrofitting cooling equipment built before 1987 . This provides a window of opportunity for particularly cost-effective retrofitting of buildings to reduce their cooling load, since cooling-load reduction will allow downsizing of the replacement-cooling equipment. The resultant capital-cost savings in turn will partly offset the upfront cost of the measures needed to reduce the cooling load, and is in addition to the reduced energy costs associated with the cooling-load reduction. The measures available to reduce the cooling load include comprehensive lighting retrofits, thermal envelope improvements (windows, insulation, air leakage), improved ventilation-control systems, use of sensible and latent heat exchangers, and better attention to correct sizing of cooling equipment and auxiliaries such as fans and motors. Altogether, these measures can readily reduce cooling loads by $20-50 \%$ in existing buildings. Here, energy and environment are being packaged in money-saving arguments - a rhetoric that makes CFC displacement more palatable to building owners.

\subsubsection{District Heating and Cooling}

Chicago may be unique (and ahead of Toronto) in having two competing private district heating and cooling systems vying for public business. DE played a bro$\mathrm{ker} /$ catalyst role in bringing adoption of the first system, which combined district heating and cooling with the co-production of electricity. Trigen Energy Company, the U.S.'s largest district heating and cooling firm, saw an opportunity in a huge private development planned for the city. But it needed an 'anchor load' to get started. DE linked Trigen with various public and private decision-makers in the City, including the Metropolitan Pier and Exposition Authority, which was able to fill Trigen's need for a base load. The system introduced by Trigen is referred to as 'trigeneration', in which the overall primary energy required to meet a mix of heating, cooling and non-heating or cooling electric loads can be reduced by about $20 \%$. This savings results largely from the displacement of independently generated electricity at large, central power plants where the efficiency is typically $31-33 \%$. The trigeneration system in Chicago is fueled by natural gas (with a $\mathrm{CO}_{2}$-emission factor of $13.5 \mathrm{~kg} \mathrm{C} / \mathrm{GJ}$ ), and displaces coal-fired electricity (with an emission factor of about $25 \mathrm{~kg} \mathrm{C} / \mathrm{CJ}$ ), so that the overall $\mathrm{CO}_{2}$ savings will be about $50 \%$. District cooling provides a more efficient alternative to building-by-building replacement of existing chillers. The pending phaseout of CFCs thus provided Chicago a window of opportunity for the adoption of district heating and cooling systems as well as energy conservation.

Trigen's potential success brought the second system, run by Commonwealth Edison, into the district heating and cooling business via a subsidiary, Northwind. This entity plans to use off-peak energy to make ice chilled water for various customers. The Chicago Symphony Orchestra is an early customer. Unlike Trigen's system, the Northwind system is not trigeneration. Since the emergence of compe- 
tition, the DE's role has been one of maintaining equitable access and competitive market through its control of public rights of way (Williams, 1995a, b).

\subsubsection{Transportation}

Transportation is perhaps the most serious global warming producing problem in Chicago. Key arteries in the City become clogged with cars, including the magnificent Lakeshore Drive. The cars (and lack of land-use planning) cause the City to continually sprawl outward, making land-use not only inefficient, but also damaging to the environment. As noted, smog is of particular concern in Chicago.

In the case of transportation, the trigger for action has been the DE Director of Public Affairs, Debra Boldt, who was hired by Williams in 1992 and has made transportation-related $\mathrm{CO}_{2}$ reduction her special mission. What she brought was a knowledge of ICLEI and its networking among cities pioneering in $\mathrm{CO}_{2}$ reduction. She made as a condition of her accepting the job that Chicago become a member of ICLEI. That consummated, she got Chicago to adopt ICLEI's Green Fleets program.

The City has a huge number of vehicles: police cars, garbage trucks, patrol boats, and fire trucks. The idea is to use municipal fleets as a test bed for innovation involving selected power systems and less-polluting fuels. This requires an alliance among the City, business, and universities. In using fuel cells as powering devices, Chicago has even become involved through the Illinois Institute of Technology in the Department of Defense's effort to find civilian uses for military technology.

In addition to working with various agencies that have fleets, $\mathrm{DE}$ has negotiated with Chicago's independent transit system to get it aboard the effort to find alternative fuels that pollute less. All these fleet programs are helped by outside money, especially federal money from DOE, the Highway Administration, and EPA. Millions of dollars have been brought to Chicago through various Green Fleet efforts. In September 1995, Chicago became the host city for ICLEI's Conference on Green Fleets. Chicago is hoping to construct new light rail lines which could substantially reduce individual vehicle use.

Through transportation as with buildings and trees, Chicago has received attention from proponents of global warming mitigation. The local entrepreneurs do not use the rhetoric of global warming, which seems too macro and alarmist to many politicians in the City. They speak more of positive impacts, such as energy savings, smog mitigation, and the alleviation of traffic congestion. They did not use the 1995 heat wave in Chicago, which killed over 500 people, to dramatize their campaign. The primary local entrepreneurs are bureaucrats, and they work for the Mayor, who was soundly criticized for lack of preparedness for that heat wave.

The administrators have a sense of climate policy that helps them see how various parts of $\mathrm{CO}_{2}$ reduction and energy-conservation activities fit together. But they do not use it as a selling technique (Boldt, 1995b). The City and various environmental groups created in 1994 a 'greenhouse' gas agenda to inform citizens of the need to address the $\mathrm{CO}_{2}$ issue. But different arguments - especially money-savings 
- are the ones the local entrepreneurs use to get politicians, other administrators, and the business community aboard.

\section{Conclusions}

The policy process model used above is helpful in comparing activities in climate change across cities and time. What it shows is that while local climate policy is developing in a fragmented fashion, it is developing nevertheless. Global warming is on the agenda of a growing number of cities around the world, some of which have adopted programs to reduce greenhouse-gas emissions and/or to deal with the impacts they expect. A worldwide network of cities concerned with $\mathrm{CO}_{2}$ impacts has grown. ICLEI's Urban $\mathrm{CO}_{2}$ Project started from a founding group of 12 cities. It has evolved into the successor program of Cities for Climate Protection, which now boasts over 100 cities around the world.

Toronto was one of the founding ICLEI cities, while Chicago is now in the follow-up program. This sequence reflects the relative salience of global warming in the two cities. For Toronto, climate policy has been a self-conscious part of the political rhetoric, while Chicago has invoked climate-change policy per se to a much lesser extent. Its approach has been more function-specific, with programs in tree-planting, buildings, district heating and cooling, and transportation, rather than using climate change as a comprehensive theme. Still, climate policy is making its way up the consciousness scale in Chicago.

The key factors in policy development in Toronto were: (1) the existence of an environmental consciousness in the culture of the City that is long-standing and affects the political leadership. This was triggered in the direction of global warming by the Changing Atmosphere Conference held in Toronto in 1988, an extremely hot year; (2) the existence of a strong local proponent of action on reducing greenhouse-gas emissions, one who was an astute and powerful politician; and (3) a growing constituency of supporters for action motivated by various values - from environmental to economic. This third factor has been particularly important in sustaining interest at a time of economic difficulty in Toronto, when the weather was not hot.

As for Chicago, the following factors are relevant. First, Chicago does not have the environmental consciousness of Toronto, but it does have a modest consciousness, as attested by various environmental groups and the Mayor's own interest in esthetics. Second, Chicago's entrepreneurs did not have the influence of a dedicated politician who put climate change on Toronto's agenda, but they did have a measure of influence. They have been bureaucratic entrepreneurs, helped by a political ally in the City Council. Moreover, the Department of Environment in the Daley regime has provided a supportive base from which they can operate. Third, there has been a growing constituency in Chicago for $\mathrm{CO}_{2}$ reduction and the economic arguments 
have been very important in promoting and sustaining interest in climate-change issues.

Perhaps the key difference in policy development between Toronto and Chicago is the linkage of Chicago and federal programs as sources of funds. Toronto has been more self-sufficient in its initial climate policy, but expects to use the private sector to provide up-front financing for district energy and building retrofit measures. The private sector has already been central to the development of Chicago's district energy systems. Proposed federal funding cutbacks in the U.S. will pressure Chicago also to become more self-reliant in the future. In that event, local economic benefits of $\mathrm{CO}_{2}$ mitigation and other climate-change strategies will become increasingly critical to global warming policy at the local level. The process of policy development will continue.

\section{Acknowledgments}

This research was done as part of a Cooperative Agreement between the Illinois State Water Survey and the National Oceanic and Atmospheric Administration under NA27RA0173-01. The considerable help of those interviewed is appreciated.

\section{References}

Boffey, Philip: 1992, 'Japan Confronts Global Warming', New York Times, July 19, 1992, p. 16E. Bolt, Debra, City of Chicago, interview Sep. 1, 1995a, Nov. 9, 1995 b.

Changnon, S. A.: 1989, 'The Drought, Barges, and Diversion', Bull. Amer. Meteorol. Soc. 70, 1092 1104.

Changnon, S. A.: 1993, 'Changes in Climate and Levels of Lake Michigan: Shoreline Impacts at Chicago', Clim. Change 23, 213-230.

Changnon, S. A.: 1995, 'State Roles on the Global Climate Change Issue', Bull. Amer. Meteorol. Soc. 76, 227-233.

Chicago Urban Forest Climate Project: 1992, 'Chicago Urban Forest Climate Summary', News Bull. March 1992.

Committee on Environment and Natural Resources: 1994, Our Changing Planet-The FY 1995 U.S. Global Change Research Program, National Science and Technology Council, Washington, DC, $132 \mathrm{pp}$.

Dalfes, H.: 1992, 'Climate Change and Istanbul: Some Preliminary Results', in McCulloch, James (ed.), Cities and Global Change, Climate Institute, Washington, DC.

Davidson, A. and Kana, T. W.: 1988, 'Future Sea-Level Rise and Its Implications for Charleston, South Carolina', in Glantz, Michael H. (ed.), Societal Responses to Regional Climatic Change: Forecasting by Analogy, Westview Press, Boulder, CO.

Edgerton, L.: 1992, 'Warmer Temperatures, Unhealthier Air and Sicker Children', in McCulloch, James (ed.), Cities and Global Change, Climate Institute, Washington, DC.

Feldman, D. L. and Mann, D.: 1991, 'Policy Analysis and the Management of Climate Change: Institutional Adaptability in the Face of Scientific Uncertainty', Policy Studies J. 19, 43-49.

Ferg, J. A.: 1992, Environmental Coordinator, Department of Environment, interview May 13, 1992. Foute, S. and Andrews, S.: 1992, 'Denver, Colorado's $\mathrm{CO}_{2}$ Transportation Strategies', in McCulloch, James (ed.), Cities and Global Change, Climate Institute, Washington, DC.

Global Climate Coalition: 1994, Climate Watch, Vol. 2(8), 6 pp.

Global Environmental Change Report: 1994, Vol. 6(19), 8 pp. 
Green, C. L.: 1992, 'Urban Air Quality and Public Health', in McCulloch, James (ed.), Cities and Global Change, Climate Institute, Washington, DC.

Harvey, L. D. D.: 1992, 'Implementation of Mitigation at the Local Level: The Role of Municipalities', in Majumdar, S. K., Kalkstein, L. S., Yarnal, B., Miller, E. W., and Rosenfeld, L. M. (eds.), Global Climate Change: Implications, Challenges, and Mitigation Measures, Pennsylvania Academy of Sciences, Easton, PA, pp. 423-438.

Harvey, L. D. D.: 1993, 'Tackling Urban $\mathrm{CO}_{2}$ Emission in Toronto', Environment 35, 16-20, 38-44.

Harvey, L. D. D.: 1995, 'Local Actions to Reduce Greenhouse Gas Emissions in the Context of National Action Plans', National Action to Mitigate Greenhouse Gas Emissions, Proc., Copenhagen, 7-9 June, 1994.

Hoffman, J. S., Keyes, D., and Titus, J. G.: 1983, Projecting Future Sea Level Rise: Methodology, Estimates to the Year 2100, and Research Needs, EPA 230-09-007, U.S. Environmental Protection Agency, Washington, DC.

ICLEI, The International Council for Local Environmental Initiatives: 1991, 1991-1993 Strategic Plan.

Inman, D. R.: Deputy Commissioner, Department of Environment, interview May 13, 1992.

Jessup, Philip: ICLEI, interview March 11, 1992.

Jones, B. S.: 1991, 'State Responses to Global Climate Change', Policy Studies J. 19, 73-82.

Kempton, W.: 1991, 'Lay Perspectives on Global Climate Change', Global Environmental Change: Human Policy Dimensions 1, 183-208.

Kempton, W. and Craig, P. P.: 1993, 'European Perspectives on Global Climate Change', Environment 35, 17-20, 41-45.

Lee: Lake Michigan Federation, interview May 13, 1992.

Macaitus, William: Metropolitan Water Reclamation, interview May 14, 1992.

Makra, Edith: Department of Environment, interview March 12, 1992.

McCulloch, James (ed.): 1992a, Cities and Global Change, Climate Institute, Washington, DC.

Morandi, L.: 1990, Global Climate Change: State Policy Development Amid Scientific Uncertainty, National Conference of State Legislatures, Washington, DC.

Nishioka, S., Moriguchi, Y., and Yamamura, S.: 1992, 'Megalopolis and Global Change: The Case of Tokyo', in McCulloch, James (ed.), Cities and Global Change, Climate Institute, Washington, DC.

Newman, P. W. G. and Kenworthy, J. R.: 1989, Cities and Automobile Dependence, Gower International, Aldershot, $388 \mathrm{pp}$.

Nowacki, Karen: Department of Environment, interview, November 9, 1995.

O'Donohue, Tony: Member of City Council, Toronto, interview March 11, 1992.

Oppenheimer, M. and Boyle, R. H.: 1990, Dead Heat: The Race Against the Greenhouse Effect, Basic Books, New York.

Schneider, S. H.: 1989, Global Warming: Are We Entering the Greenhouse Century?, Sierra Club Books.

Smith, M. A.: 1995, New Directions for Clean Air in Chicago, Paper presented at the Second Municipal Leaders Summit for Climate Protection, Berlin, 9 pp.

Special Advisory Committee on the Environment (SACE): March 1991a, The Changing Atmosphere: Strategies for Reducing $\mathrm{CO}_{2}$ Emissions Policy Overview, Report No. 2, Vol. 1, City of Toronto, Toronto, Ont.

Special Advisory Committee on the Environment (SACE): March 1991b, The Changing Atmosphere: Strategies for Reducing $\mathrm{CO}_{2}$ Emissions Technical Volume, Report No. 2, Vol. 2, City of Toronto, Toronto, Ont.

U.S. State Department: 1994, U.S. Climate Action Report, Washington, DC.

Williams, Charles H.: Director of Energy Management, Department of Environment, interview May 13, 1992, September 15, 1995a, and November 9, $1995 \mathrm{~b}$.

(Received 12 December 1994; in revised form 29 May 1996) 